\title{
Controlling and Corporate Social Responsibility: A Comparative Study of German and Estonian Controlling
}

\author{
Lea Roostalu \\ Estonian Business School, Tallinn, Estonia \\ Siret Pihelgas \\ Mainor Business School, Tallinn, Estonia
}

\begin{abstract}
This paper focuses on the functions of controlling in Estonia and Germany. The analysis based on the study carried out in Estonian enterprises in 2008. The study was conducted by the Estonian work group of the International Controller Association ICV (internationaler controller verein). The methodology and controlling questionnaire were the same, which were used by the German work group of ICV in 2006. The mentioned questionnaire was also worked out in Germany by Otto Beisheim School of Management. The authors compared the results of both studies. Cultural differences and their impact on the tasks of controllers were also scrutinized. The results of the research indicate that the tasks of Estonian controllers are strictly fixed with procedure documents, which leaves very little room for independence and initiative. Usually, they are not involved in the strategic planning and goal setting. The final conclusion is that the sustainability function of controlling is much more on the background compared to other functions of controlling, but in the future the role of this function is expected to increase.
\end{abstract}

Keywords: controlling, the international controller association ICV (internationaler controller verein), corporate social responsibility (CSR), sustainability, Estonia, Germany

\section{Introduction}

Corporate social responsibility (CSR) promotes a vision of business accountability to a wide range of stakeholders. Key areas of concern are environmental protection and the well being of employees, the community and civil society in general, both now and in the future. The CSR concept started to attract increased attention with the work of Bowen (1953), which focused on the obligations of business toward the expectations of the very society that permitted its existence and conferred on its legitimacy.

"In the current exceptional circumstances, corporate social responsibility is even more crucial than ever", said European Commission President José Manuel Barroso speaking at CSR Europe's General Assembly in Brussels on June 11, 2009 (Website of CSR Europe, 2009). Barroso said: "The crisis resulted, in part at least, from a failure by some businesses to understand their broader ethical responsibilities. Now all businesses must

Lea Roostalu, MBA, Ph.D. candidate, Lecturer, Behaviour Sciences, Estonian Business School.

Siret Pihelgas, MBA, Assistant, Entrepreneurship, Mainor Business School.

Correspondence concerning this article should be addressed to Lea Roostalu, Lauteri 3, 10114 Tallinn, Estonia. E-mail: lea.roostalu@tallinnlv.ee. 
rise to the challenge" (Ibid.).

CSR has a vital "people" dimension and therefore a strong connection with human resources management, which makes perfect business sense for human resources (HR) to play a key role in CSR because implemented properly, a forward-thinking CSR policy in a company can turn HR from just an administrative function into a key partner in the board room (Valentino, 2007). In this context HR needs to create systems and policies that set the tone for an organizational culture that is open to and understands CSR (Ibid.).

The role of controlling is working out and presenting effective technologies for the realization of the management function, i.e., the creation of an organizational-methodological complex of methods, methodologies, and instruments in order to guarantee the definite achievement of the goals that are set by the management (Horvath, 2006; Falko, 2008).

This paper examines Estonian controlling adjustment to changes in the management needs in the current economic situation - is it contributing to the sustainable development and integration of CSR principles in the business activities. The empirical study of Estonian controlling was conducted in 2008 by the authors, who are the members of the Estonian controlling organization. The results were compared with the results of the German study (Weber, 2006), which was conducted by the German controlling organization. Both organizations belong to the International Controllers Association ICV. As Estonian national culture has for a long time been influenced by German national culture and both countries belong to the same cultural room, the authors analyzed the cultural aspects, too.

\section{Theoretical Background}

\section{Corporate Social Responsibility and Sustainability}

The concept of Corporate Social Responsibility does not have a generally understood meaning. In the European Union, CSR is a part of the official policy as a factor improving competitiveness and the EU definition of CSR is: "A concept whereby companies integrate social and environmental concerns in their business operations and in their interaction with their stakeholders on a voluntary basis". Although the concept of CSR dates from the fifties of the last century (Norris \& Innes, 2005) and the theoretical perspectives of CSR have been developed for over two decades (Carroll, 1979; Freeman, 1984; Donaldson \& Preston, 1995; Clarkson, 1995; McWilliams \& Siegel, 2001), its practical implementation has increased in importance only in the last decade (Kawamura, 2004; Balmer, Fukukawa, \& Gray, 2007).

CSR develops the economic performance, the reputation and employee relations of businesses, improves their compliance with legislation and enhances their risk management (Freeman, 1984; Matten \& Moon, 2004).

CSR can also be understood as the business contribution to sustainable development. The principle of sustainability and CSR is well conveyed by the new organizational management model, which was described by Johannes Rüegg-Stürm (see Figure 1).

Hence, the concept of CSR is underpinned by the idea that corporations can no longer act as isolated economic entities operating in detachment from broader society. Traditional views about competitiveness, survival and profitability are being swept away. Organizations begin to recognize that their role goes beyond a purely economic one, and it has certain other duties and obligations (Reidenbach \& Robins, 1991). Juščius and Snieška (2008) claim that only the companies that aim to save all universally accepted ethical standards of social 
behaviour can expect a positive attitude and support in the modern society. Nowadays, corporate social responsibility is an integral part of the business vocabulary and is regarded as a crucially important issue in management (Cornelius, Todres, Janjuha-Jivraj, Woods, \& Wallace, 2008; Humphreys \& Brown, 2008).

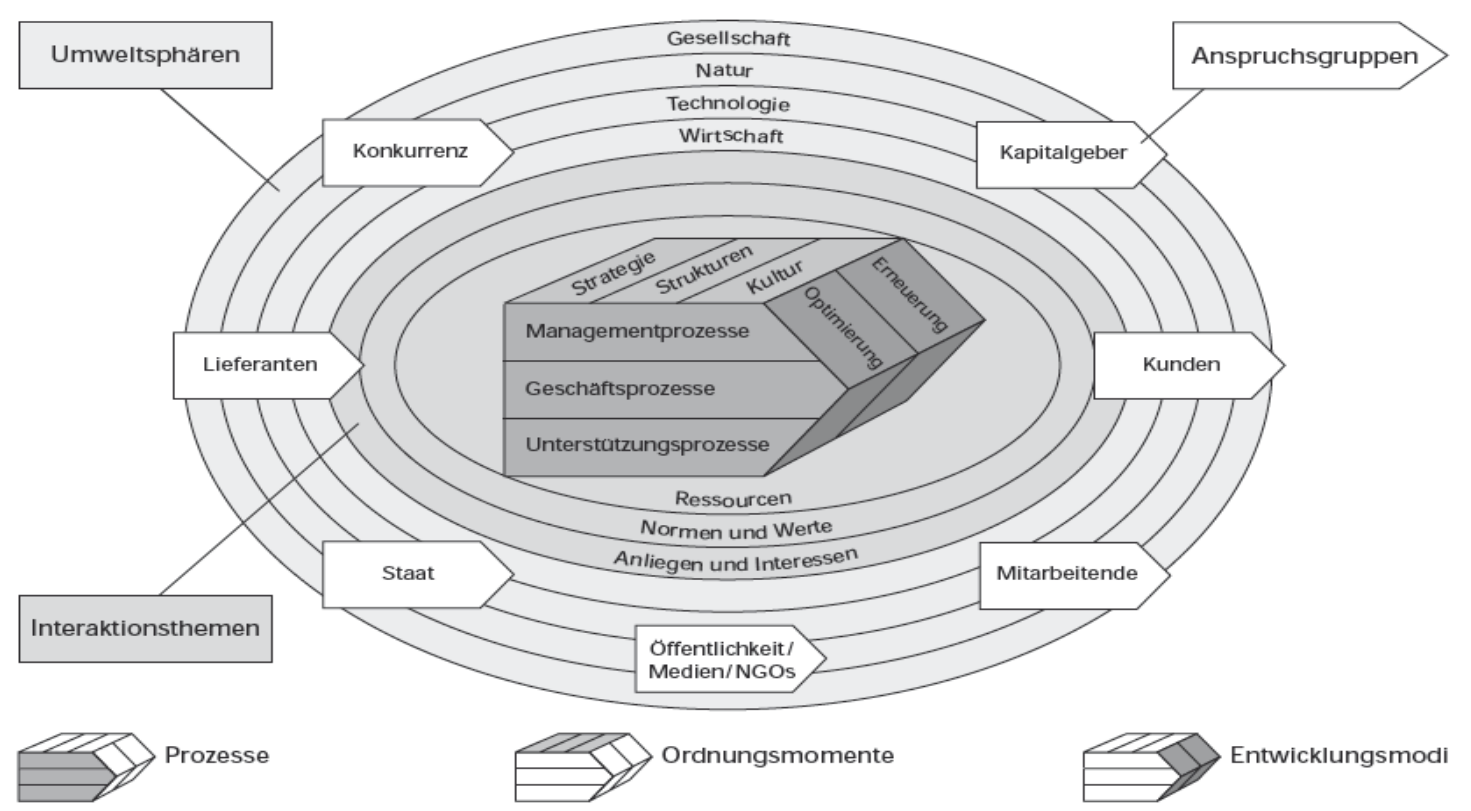

Figure 1. Organizational management model. Source: Rüegg-Stürm, 2002.

The Review of the European Union Strategy for Sustainable Development (2009) confirms:

Greater commitment to CSR on the part of European enterprises will enhance Europe's capacity for sustainable development. The Commission and many EU Member States have intensified their efforts to promote the uptake of CSR, with the emphasis on dialogue between stakeholders.

Many authors (Nejati, Shahbudin, \& Amran, 2010; Geertshuis, 2009; Heidmets, 2004) point out the significance of knowledge-based decision-making in the context of sustainability, and they suggest that both technological and social innovation are essential parts of sustainable development. In 2010, the need of the knowledge society was also under investigation in the report of the European Commission "sustainable development indicators" as a further need in view of EU (Adelle \& Pallemaerts, 2010).

\section{Organizational and National Culture}

In the last ten years, multiple studies have been conducted to analyse the relationship between CSR and culture. Some authors (Hillman \& Keim, 2001; Wieland, 2005; Rooney, 2007; Thornton \& Jaeger, 2008) have found that there has to be congruence between organizational culture and CSR, and they claim that in general CSR should be seen as an embodiment of organization's culture and values. Many empirical studies have confirmed that individual and organizational values are significant predictors of CSR managerial behaviour (Branzei, Ursacki-Bryant, Vertinsky, \& Zhang, 2004; Vitell \& Paolillo, 2004; Hemingway, 2005; Waldman, de Luque, Washburn, \& House, 2006). Übius and Alas (2009), according to their study in eight countries, have proved that three organizational types — clan, hierarchy and adhocracy culture - predict two facets of CSR (i.e., organization performance concerning social issues and organization respects the interest of agents), and the 4th 
organizational culture type-market culture-predicts one facet of CSR (i.e., organization performance concerning social issues).

For change to be successful, there have been debates whether the organizational culture should be changed accordingly (Cameron \& Quinn, 1999; Denison, 2001) or the change has to be positioned within the dominant organizational culture paradigm (Schein, 1999; Trompenaars \& Prud'homme, 2004). According to Lyon (2004), developing a CSR orientation is possible only if a supportive organizational culture emerges within the organization. This statement highlights that an organization must achieve a deep comprehension of the ethical and cultural developments associated with CSR if it wants to reach a genuine CSR orientation (De Woot, 2005). Developing CSR initiatives thus often demands the cultural evolution of the organization. Moreover, organizational cultures can represent information, knowledge, and know-how that may support or spoil CSR efforts (Doppelt, 2003).

A lot of authors have studied the relationships between organizational and national culture, and found that national culture as an environmental factor has an impact on organizational culture (Hofstede, 1994; Matsumoto, 1996). Hofstede defines national culture as the collective mental programming of people in an environment, which can be characterized by the following four dimensions (Hofstede, 2001):

(1) Power distance;

(2) Uncertainty avoidance;

(3) Individualism or collectivism;

(4) Masculinity or femininity.

As Hofstede's culture dimensions are based on deeper values, i.e., on the level of national culture, they are not suitable for comparing organizations within the same country. At a later time, Hofstede has also added the 5th dimension, which describes long- or short-term orientation, and does not have any links to the other four dimensions. Hofstede's dimensions have been proved as very useful and highly relevant. Although they cannot give a fully satisfying explanation to every culture related behaviour, they mostly give a tendency towards reasoning (Hengstamm \& Becker, 2006).

Some researchers have analysed the impacts of national culture on CSR. Waldman et al. (2006) have shown that while institutional collectivism predicts the values of CSR in a positive direction, in-group collectivism had no significant effect on CSR. Additionally, Ringov and Zollo (2007) have found that cultural differences with respect to individualism had no significant effect on CSR. Chen, Lee-Chai and Bargh (2001) claim that individuals with communal orientation demonstrate greater socially acceptable views and norms, which means that they link power with responsibility goals. Ringov and Zollo (2007) and Scholtens and Dam (2007) have concluded that masculinity has a significant negative effect on corporate social performance and ethical policies. Husted (1999) has proved that managers in countries that can be characterised by high power distance, masculinity and uncertainty can easily engage in corrupt business behaviour.

\section{Controlling}

First of all, the conception of controlling should be opened, which is accepted by the international controller organization ICV and would describe the nature of controlling in an enterprise (Deyhle, 2002; Blazek, Deyhle, \& Eiselmayer, 2005, p. 33): The manager is responsible for results, money, processes and strategy, while the controller is responsible for the transparency of results, money, processes and strategy. 
Controlling has various aspects of defining, among other things (Blazek et al., 2005; Horvath, 2006; Falko, 2008; Weber \& Schäffer, 2008):

- The etymological aspect — controlling as supervision, management, guidance, regulation, review;

- The conceptual-instrumental aspect-controlling as presentation of methods, instruments, conceptual means to the management for the fulfilment of the control and planning processes, but also the coordination and integration of these processed with all functional units;

- The ethical-moral aspect—controlling as the company's "economical conscience";

- The philosophical aspect - controlling as a philosophy and mentality of the workers that is based on the rational use of resources and understanding the need for synchronization and harmonization, for taking into account the co-workers, clients and other interest groups, and the company's interests with the goal of guaranteeing the company's long-term existence and development.

Management accounting, which in the viewpoint of ICV is a part of controlling, is defined as:

Value-adding continuous improvement process of planning, designing, measuring and operating both non-financial information systems and financial information systems that guides management action, motivates behaviour, and supports and creates the cultural values necessary to achieve an organization's strategic, tactical and operating objectives. (Atkinson, Kaplan, Matsumura, \& Young, p. 643)

As management accounting comes more and more close to controlling, some authors claim that there are no differences between management accounting and controlling. In our opinion, the word "accounting" does not fully convey the meaning, even if one day these two notions would be synonyms.

The leader of the Russian controlling, professor Sergey Falko, has pointed out the phases of controlling development (Falko, 2008, p. 13):

(1) Recording;

(2) Estimative-analytic;

(3) Integrative within the company;

(4) Coordinating-navigating;

(5) Optimizing the interests of stakeholders.

As the last of these phases - optimising the interests of stakeholders - will be directly conveyed by the concept of CSR, our conclusion is that today controlling is becoming a means for corporate social responsible management.

According to Professors Jürgen Weber and Utz Schäffer (2008, p. 28) nowadays controlling has the following four functions:

- Collection, processing and transmission of information - management support via provision of information;

- Planning and control as performance orientation;

- Coordination within the organization and all level of management system;

- Sustainability orientation or provision of sustainable development for the organization.

The functions of controlling are coming up step by step as the phases of controlling development. Initially, the sustainability function was seen as guaranteeing financial sustainability (in the original: Razionalitätssicherung), but today, this function has acquired a broader meaning that has developed together with the concept of sustainability and CSR. 


\section{Empirical Data and Analysis}

\section{Research Context and Sample}

Mari Kooskora, Head of the Ethics Centre at Estonian Business School, focused in her dissertation on business ethics and corporate moral development in Estonia (Kooskora, 2008). The results of her study, based on data collected from 88 Estonian companies in 2005 showed that at this time, the notion of CSR was not clear and most of the companies did not see it as a part of their strategy. In general, it can be said that the modern business environment in Estonia is relatively young and companies are still coming to understand new methods and new paradigms such as CSR (Kooskora, 2008, p. 71).

The results of the Estonian CSR index in 2007 and 2009, obtained by Responsible Business Forum in Estonia, pointed that CSR awareness is still low and based on the given index the risks for Estonian companies are integrating the principles, and assessing and communicating the results (Website of Responsible Business Forum in Estonia, 2009). Estonia is the first Eastern-European country that has started to put together the responsible business index. In 2007, only 14 companies participated in putting together the index and in 2009, 49 companies.

Based on these facts, our hypothesis was that controlling in Estonia has not been active in the field of CSR. There are no data on controlling studies in Estonia—some authors have studied the use of management accounting information, which is not comparable to the whole controlling area. It can be said that both controlling and CSR far from their relationship are unknown topics for Estonian publicity. Moreover, the authors of the present article have no information about any studies focused on CSR and controlling all over the world, and the only one controlling study, which among other things touched upon sustainability was conducted in 2006 by a German controlling organization.

The study of Estonian controlling was carried out in 2008. We conducted it by the network of the Estonian controlling organization and had altogether 40 respondents, which quantitatively is not high, but the main business domains were represented. The feedback percentage was very good as we sent out 60 e-mails. The respondents (mostly the controllers) had been in their current positions for around 5 to 8 years, which provided a high level of continuity. The average age of the respondents - 39 years — was high and shows that experience is a prerequisite for this job. The companies taking part in the study employed around 300 employees. As the benchmark for our study was the study of German controlling in 2006 it could be said that German controllers are also not very young - most of them were older than 35 years, and their average period on the current position was 1-5 years.

\section{Purpose and Methodology}

The main purpose was to survey the current position of Estonian controlling, especially in respect to corporate social responsibility and sustainability. As one of the targets was to compare German and Estonian controlling, this case study can be characterized as a comparative one.

In the study of Estonian controlling, the same questionnaire concerning the present situation and future trends in controlling was used, which was designed by Otto Beisheim School of Management and used in Germany by the work group of German controller organization in 2006 (Weber, 2006). The questionnaire comprises 7 main blocks and each block includes up to 55 questions. A 7-point scale was used, where "1" indicates "strongly disagree" and 7 "strongly agree".

Additionally, we attempted to explore the impact of cultural context on the work of controllers in Estonia 
and Germany for a better understanding of similarities and differences between their work. There we used Hofstede's framework of cultural dimensions and their index values in both countries (see Figure 2).

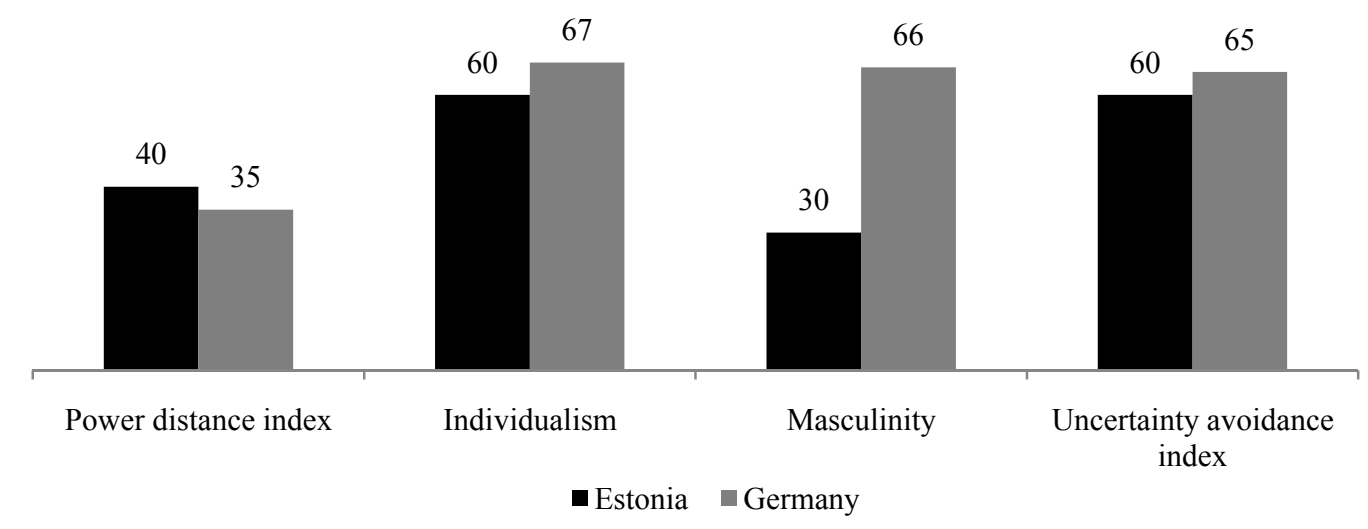

Figure 2. Hofstede's cultural dimensions in Estonia and Germany. Source: The Website of Hofstede's works.

Our analysis was based on the interpretation of the results of both studies.

\section{Results of the Case Study}

In this section, understanding the controlling functions and tasks as well as the mandates, skills and roles of controllers are under investigation.

Understanding the controlling functions and tasks. At first we found that in both of the countries the distribution of the controllers' work time between the controlling functions is very similar (see Figure 3). Planning and control takes more time than other functions, this is followed by provision of information and sustainability function, and the last position is held by coordinating.

There were some differences between assessments on the importance of these functions (see Figure 4): In Germany, planning and control was on the 1st position and sustainability held the 3rd place while in Estonia, sustainability held the 4th place and provision of information held the 1st place. In Germany, there were 618 respondents, and the results of their study showed that sustainability was assessed as the most important function of controlling only in very successful companies and the succession of the functions, which appeared in Estonia, characterized the companies, which are not successful.

In Estonia, the size of the sample was relatively small and the self-assessment results of the companies were quite low. In Germany, the average assessment on the company's success was higher than in Estonia (4.8 versus 4.1). For example, the client orientation was assessed with " 3.5 " by the Estonian respondents and " 5.2 " by the German respondents. In Estonian successful companies, the succession of the controlling functions coincided with the average of assessments in Germany. So we recognized the same tendency - the sustainability function is not popular in the companies that do not have good performance.

Thirty seven percent of the German respondents believe that in the future, the most important function of controlling will be sustainability orientation (see Figure 4), while within Estonian, controllers sustainability holds the 2nd place and planning and control the 1st place, but the latter two assessments are very close to each other (28\% versus $29 \%$ ). In Germany, the importance of planning and control and provision of information are equal $(24 \%)$. 


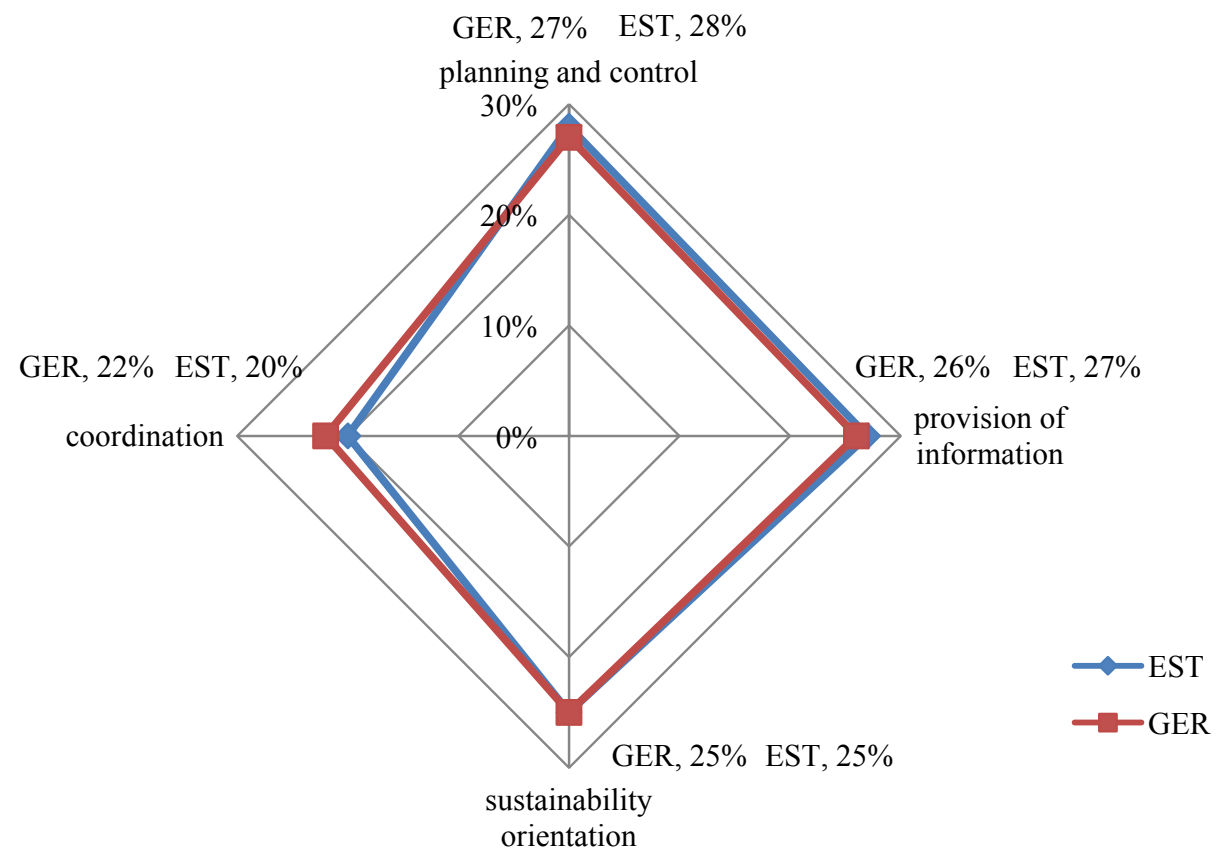

Figure 3. The rates of the controlling functions.

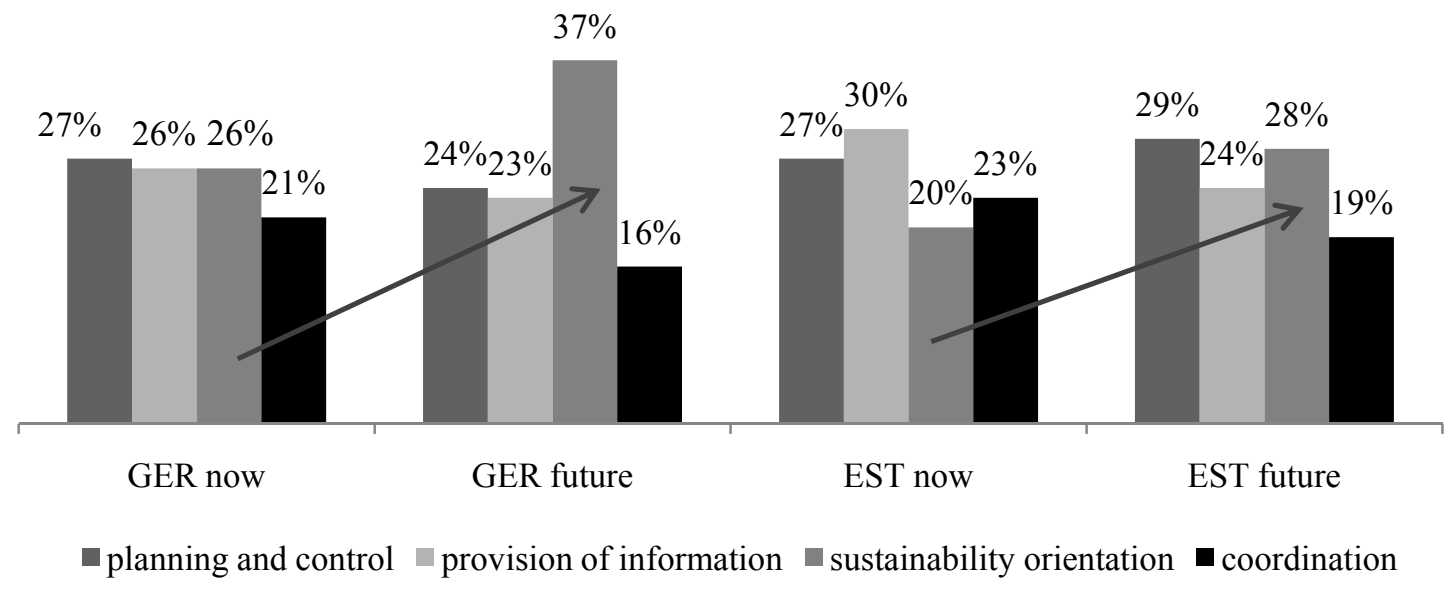

Figure 4. Significance of the controlling functions now and in the future.

The detailed vision overview on how the controlling functions were assessed by successful and unsuccessful companies in Estonia and Germany shows that all controlling functions excluding sustainability were assessed closely in German and Estonian successful companies, and also the same appeared in case of unsuccessful companies (see Figure 5). However, the assessment of sustainability function in Estonian successful companies was rather close to the assessment of German unsuccessful companies (32\% versus $31 \%$ ). We guess that the reason for the last phenomenon can be again the lower assessment on the company's success by the Estonian controllers, which does not have an impact on the other controlling functions. Hence, there should be an effect between the company's success and the value judgement to the sustainability function of controlling.

Next, we pointed out the remarkable differences in understanding the tasks of sustainability function (see Figure 6). 


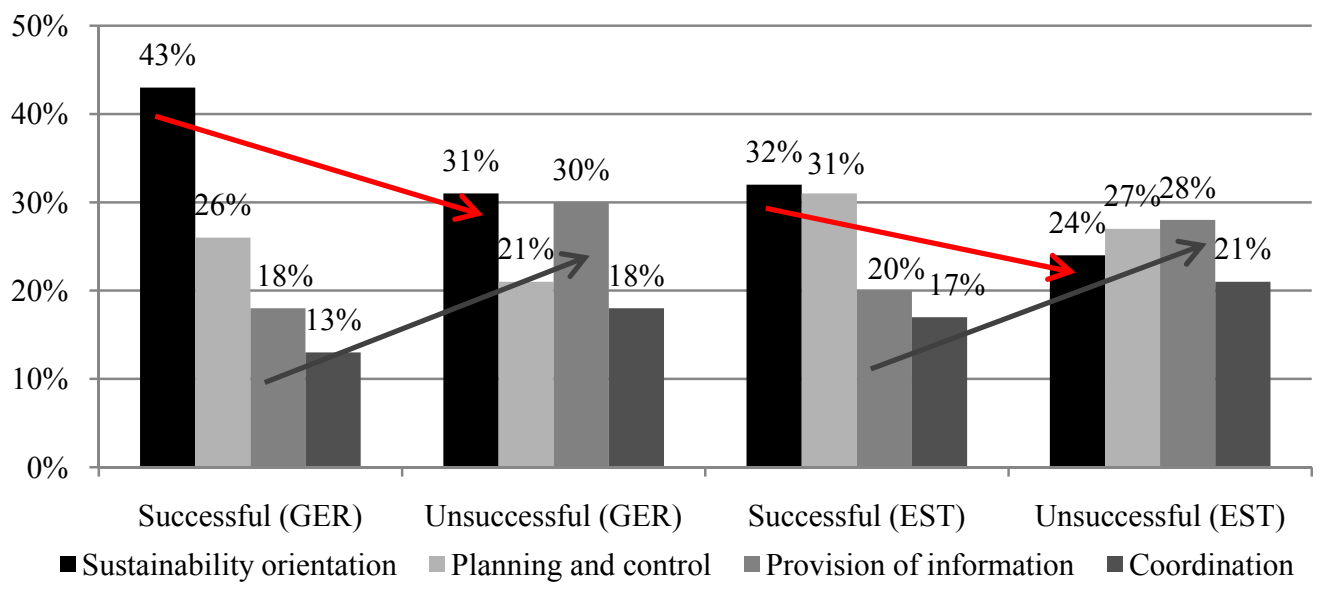

Figure 5. The future trends of the controlling functions in successful and unsuccessful companies.

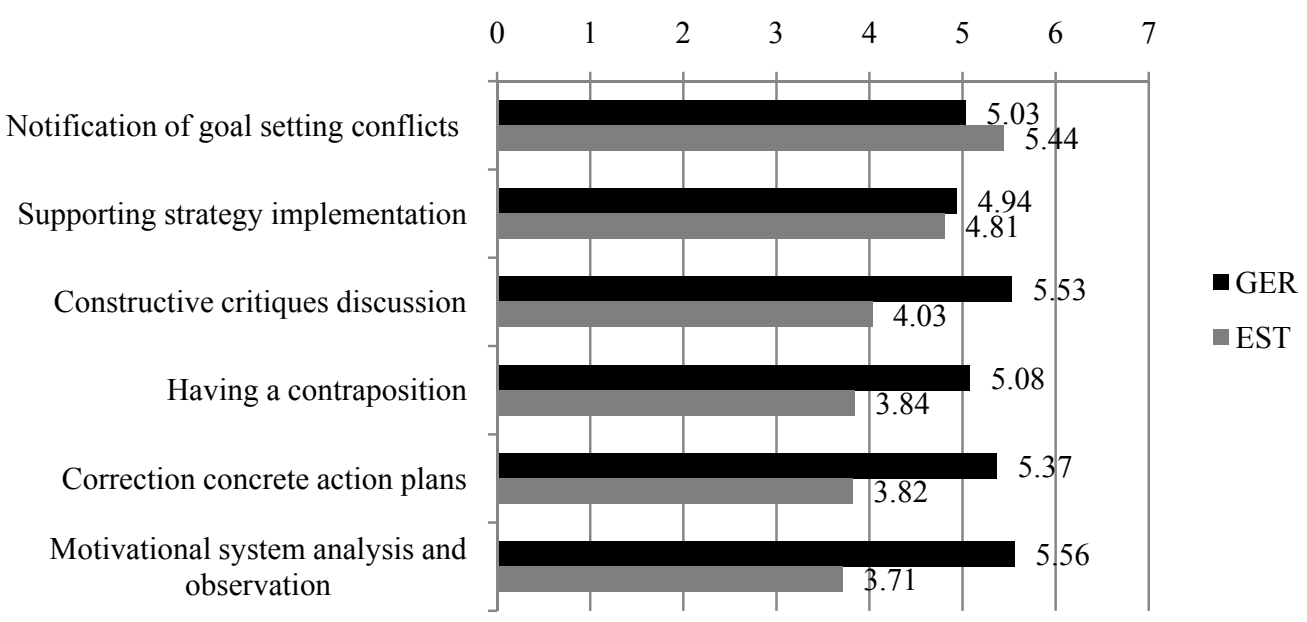

Figure 6. The tasks of sustainability function of controlling.

Estonian controllers do not like to (or they fail to) have constructive critiques discussions and they have difficulties in managing with contra-opinions, correct activities plans and motivational systems. The 3rd and 4th tasks were assessed similary by all Estonian companies, while the assessments on other tasks were assessed lower by unsuccessful companies. In the German study report (Weber, 2006), the successful factor was analyzed only in the context of controlling functions. German controllers find that the rate of having a contraposition will increase in the future and the other tasks will stay at the same level, while Estonian controllers think that the rate of constructive critiques discussion will increase.

There also were some differences in the tasks of the other functions of controlling. Based on the information function, we noticed that the Estonian controllers do not turn attention to the managers' need for information (see Figure 7). They are usually busy with technical adaptations of the information systems to meet the needs of the companies, while the most important work task for German controllers is presentation of information. In Estonia, information presentation holds the 4th place. In the future, German controllers believe that the rate of this task will stay at the same level, while Estonian controllers find that the rate of presentation will increase. In both countries, the rate of technical adaptation is expected to decrease. Unfortunately, Estonian controllers think that 
they will not be busy with information needs in the future, too. The reason for that can be the fact that this task is not fixed in Estonian controllers' work list and their initiative will not be allowed.

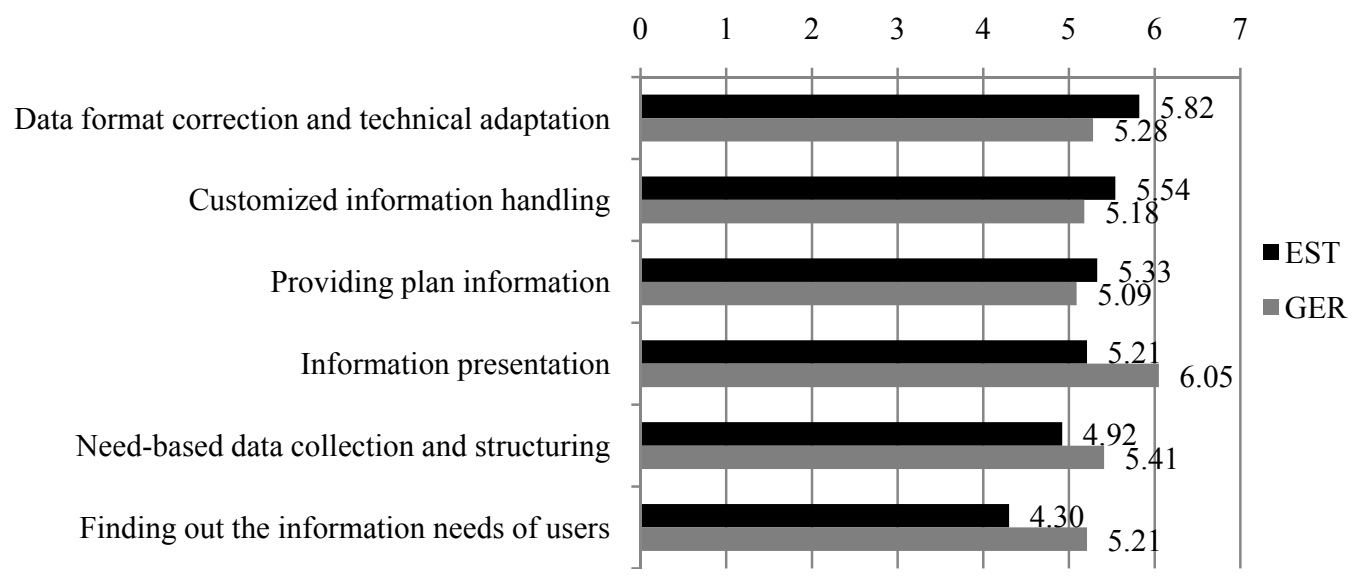

Figure 7. The tasks of information function of controlling.

By the planning and control, the two different preferences appeared: German controllers are busy with technical tasks such as control and compiling, while Estonian controllers stress the interpretation of results and improving the quality of plan (see Figure 8). German controllers are sure that in the future, the rate of analyzing will decrease, while Estonian controllers have the contrary viewpoint.

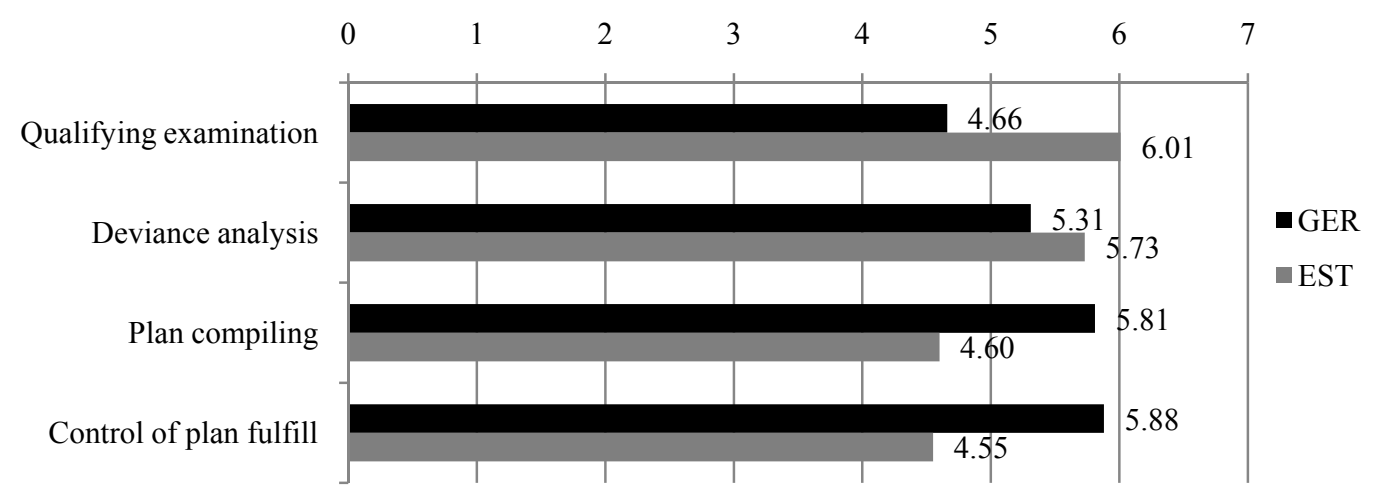

Figure 8. The tasks of planing and control function of controlling.

By the coordination function, we can again see that Estonian controllers are busy with adaptation and integration of information systems, and they prefer to be not responsible for goal and motivation system setting (see Figure 9). German controllers' main activity is the integrating of short and long term plans. In both countries, the rate of coordination within controlling organization will decrease.

In Germany, besides financing controllers also work in special fields like marketing, logistic, strategic, investment, risk management, which for Estonian controllers are exceptional. Estonian controllers are primarily financial controllers, and their main activity is comparing budget figures with actual figures. According to Falko, controllers should not deal with observing the fulfilment of plans or budgets-they work out methods, methodology and algorithms for control. Falko's vision is that controllers will be coordinators and navigators. Main cooperation partners for Estonian and German controllers come from the accounting units. However, the 
controllers in both countries believe that strategic unit workers will be their main cooperation partners. This opinion is compatible with Falko's standpoint that one of the trends of controlling is the progression of consulting service to management and the decrease in calculative-analytical work (Falko, 2008, p. 17).

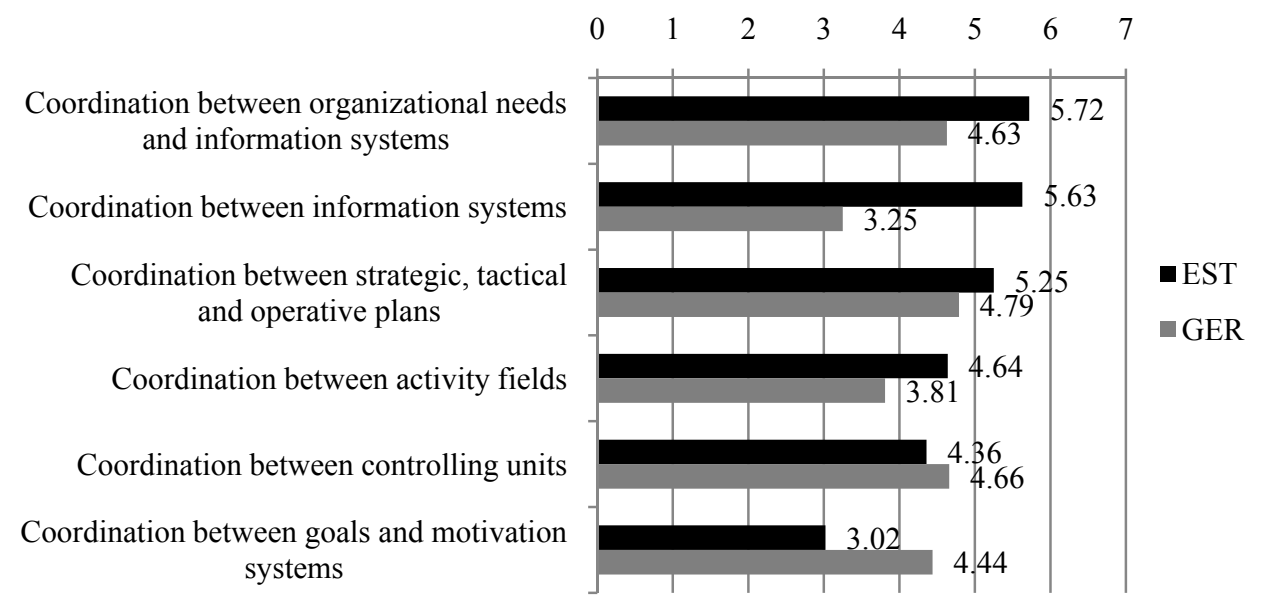

Figure 9. The tasks of coordination function of controlling.

The mandates, skills and roles of controllers. Various aspects in the relations between controllers and management were described. Both in Germany and in Estonia, management sees controllers as critical discussion partners, entrusts them and gives them free hand on how to follow orders, but in Estonia, controllers are mostly not involved in the strategic planning and goal setting. It means that in Estonia, controllers are not the first discussion partners as they are not equal with board members. The work tasks of Estonian controllers are strictly fixed with procedure documents and it leaves a very little room for independence and initiative. Assignments are given in the hierarchical method, and all the activities and decisions need to be approved by the management. German controllers feel themselves as equal partners with management, while Estonian controllers touch the barriers of hierarchy, which can be due to a little bit higher power distance in Estonia. According to Hofstede, the high need for uncertainty avoidance in both countries should be an indicator for rules, procedures and structure. Giving free hand can be reasoned with high individualism in both countries. Having critical discussion partners can be reasoned with the low power distance in both countries-employees expect to take active part in decision-making or at least to be consulted before deciding.

The overview of critical skills of controllers now and in the future (see Figure 10) shows that Estonian controllers assess teamwork while German controllers concentrate on IT and communication skills, and on standing firm. In both countries, business understanding and critical analysis as conceptual skills are important. As the keywords of femininity are belonging and brotherhood, team work assessing can be explained with low masculinity in Estonia. In Germany, masculinity has much higher level than in Estonia. This is the only bigger cultural difference between the two countries. Thus, preferring technical skills and standing firm can be derived from higher masculinity in Germany. We have to remember that in the communities with high masculinity, conflicts will be resolved by power position, while in the more feminine communities by negotiations. IT skills and teamwork can also be seen as the tools for guaranteeing certainty. Of course, the same can be said about the learning other new skills. Though we should conclude that Hofstede's five dimensions cannot be used there to 
describe all detailed skills, they are good for analyzing more universal terms. We can suppose that German controllers have a bigger certainty motivation, while in Estonia both assuring and social motivation are important. Hengstamm and Becker (2006) claim that in Germany leaders require a higher amount of technical skills in order to cope with the higher need of uncertainty avoidance, and we are glad that our study shows the same.

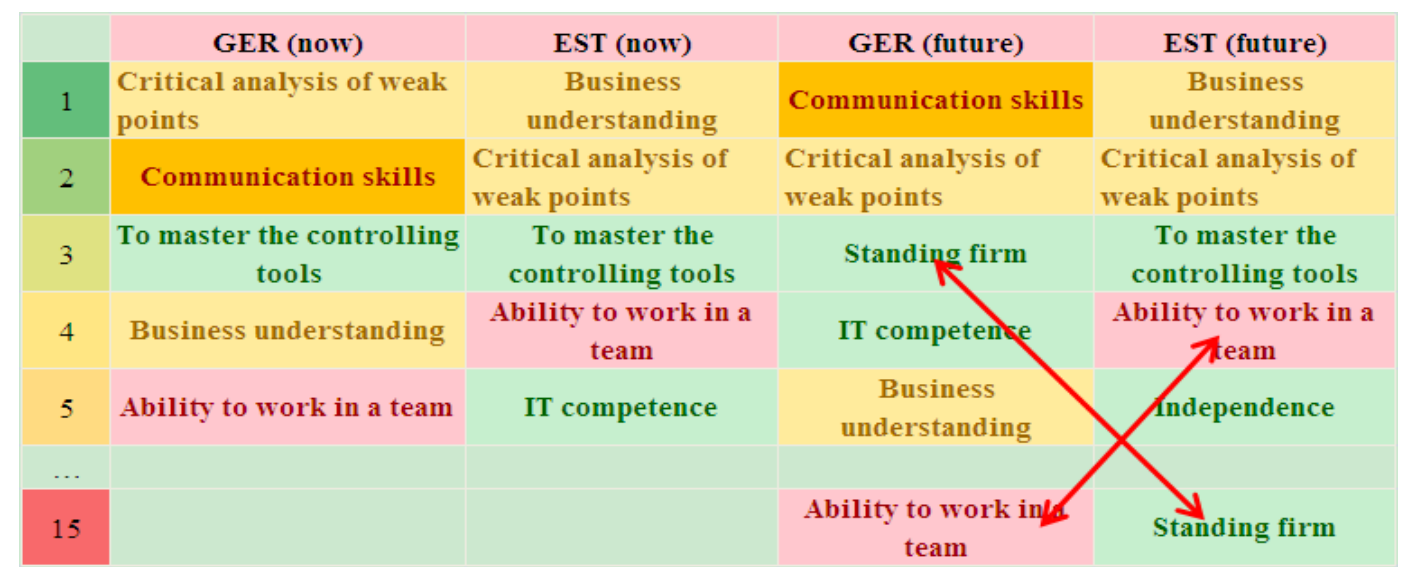

Figure 10. Critical skills of controllers.

Hengstamm and Becker (Ibid.) also proved that communication skills are critical for effective leadership in each country of their study (i.e., in Germany, England, Sweden, France), and low power distance predict better communication. There we see a reason why communication skills are more popular in Germany.

Additionally, Hengstamm and Becker (Ibid.) found that high individualism requests independence. In our opinion, independence is so natural for German controllers (which appeared in their relations with managers) that they do not perceive it as critical. Estonian controllers are not very independent but they hope to see themselves more independent in the future. According to Falko, both communication and independence would crucially increase (Falko, 2008, p. 22). We are sure that communication with all stakeholders will be an inescapable activity in the conditions of sustainable development. Already today, owing to rapid advances in online information and e-commerce, besides intra-corporate users the management accounting information is also used by business partners, suppliers and customers (Horngren, Bhimani, Datar, \& Foster, 2005). Communication skills were named in top 5 both now and in the future by Estonian successful companies.

In both countries, controllers are sure that the company's organizational culture prescribes the majority of roles contents by controllers now and henceforward and the most named roles of controllers were the same (see Figure 11) - The internal advisor, economical conscience, and inspector (kontrolleur).

There were no contrasts between successful and unsuccessful companies. In Germany, the navigator role will take the place of the inspector role in the future. In Estonia, the economical conscience role will fall on the 3rd place and the innovator role will go up on the 2nd place. In both countries, the change agent role, which was in the background, will get the 4th place. As change-oriented behaviour is directly concerned with encouraging and facilitating change and organizational development (Yukl, 2006; Hengstamm \& Becker, 2006), we can conclude that the forthcoming of new roles is in harmony with the development of controlling on a new phase and with the growth of the sustainability function, and there are no differences between the roles of controllers in the two countries. 


\begin{tabular}{|c|c|c|c|c|}
\hline & GER (now) & EST (now) & GER (future) & EST (future) \\
\hline 1 & $\begin{array}{c}\text { Internal advisor } \\
\text { Economical } \\
\text { conscience }\end{array}$ & Internal advisor & Internal advisor & Internal advisor \\
\hline 3 & Economical conscience & Economical conscience & Innovator \\
\hline 4 & Inspector & Inspector & Navigator & Economical conscience \\
\hline
\end{tabular}

Figure 11. The roles of controllers.

\section{Conclusions}

The case study focused on the controlling mission related with corporate social responsibility and sustainability, which is an actual and original topic today.

The results of the study, including the comparison of Estonian and German controlling, indicate that in both of the countries controlling is becoming a means for corporate social responsible management but in Estonia, where controlling is younger, the controlling development level is lower than in Germany. Thus, our hypothesis that Estonian controlling has not been active in the field of CSR yet was supported by the findings. The phenomenon that in unsuccessful companies the sustainability function of controlling is in the background, which appeared in the results of German controlling study, was also supported by the results of the Estonian controlling study. The role of this function is expected to increase in the future.

Hofstede's theory of five cultural dimensions was used to analyze the characteristics of the controllers' work, but we could not apply them for all characteristics as some of them were too specific. We pointed out some general differences and similarities. Whereas in Germany hard skills are becoming more significant, in Estonia the preference lies on soft skills. Conceptual skills are important in both countries. As the three personal skill dimensions - human, technical and conceptual skills-figured out by Katz are still valid and important for effective leadership (Katz, 1955; Hengstamm \& Becker, 2006), our first recommendation is that German and Estonian controllers have to pay more attention to all three of them and especially develop their conceptual skills towards CSR.

According to the study, Estonian controllers do not have the same strong position for decision-making as their German colleagues do. Our second recommendation is that Estonian managers should change this outdated mentality — controllers are no longer specific accountants and their field of activity is continually expanding. As higher masculinity makes self-validating easier, which is essential for controllers, we cannot draw any conclusions about the negative effect of this cultural dimension on corporate social performance-rather contrariwise. We are sure that the relation aspects between controlling, CSR performance and national culture should be examined in more details in further studies.

There are also limitations in this study connected with its general framework. As we wanted to compare Estonian and German controlling, we focused only on national culture, while organizational differences were neglected. We believe that the relationships between controlling and organizational culture and their impact on sustainability orientation also need to be deeply studied.

\section{References}

Adelle, C., \& Pallemaerts, M. ( 2010). Sustainable development indicators. An overview of relevant framework programme funded 
research and identification of further needs in view of EU and international activities. Brussels, European Commission, Directorate-General for Research.

Atkinson, A. A., Kaplan, R. S., Matsumura, E. M., \& Young, S. M. (2007). Management accounting (5th ed.). New Jersey: Pearson Prentice Hall, Upper Saddle River.

Balmer, J. T., Fukukawa, K., \& Gray, E. R. (2007). The nature and management of ethical corporate identity: A commentary on corporate identity, corporate social responsibility and ethics. Journal of Business Ethics, 76(1), 7-15.

Blazek, A., Deyhle, A., \& Eiselmayer, K. (2005). Controlling and the controller. Augsburg: Schoder Druck GmbH \& Co..

Bowen, H. R. (1953). Social responsibilities of the businessman. New York: Harper \& Row.

Branzei, O., Ursacki-Bryant, T. J., Vertinsky, I., \& Zhang, W. (2004). The formations of green strategies in Chinese firms: Matching corporate environmental responses and individual principles. Strategic Management Journal, 25(11), 1075-1095.

Cameron, K. S., \& Quinn, R. E. (1999). Diagnosing and changing organisational culture based on the competing values framework. USA: Addison-Wesley.

Carroll, A. (1979). A three-dimensional model of corporate performance. Academy of Management Review, 4(4), $497-505$.

Chen, S., Lee-Chai, A. Y., \& Bargh, J. A. (2001). Relationship orientation as a moderator of the effects of social power. Journal of Personality and Social Psychology, 80(2), 173-187.

Clarkson, M. (1995). A stakeholder framework for analyzing and evaluating corporate social Performance. Academy of Management Review, 20(1), 92-117.

Cornelius, N., Todres, M., Janjuha-Jivraj, S., Woods, A., \& Wallace, J. (2008). Corporate social responsibility and the social enterprise. Journal of Business Ethics, 81(2), 355-370.

De Woot, P. (2005). Should prometheus be bound? Corporate global responsibility. New York, N.Y.: Palgrave Macmilla.

Denison, D. (2001). Organisational culture: Can it be a key lever of driving organisational change? In C. L. Cooper, S. Cartwright, \& P. C. Earley (Eds.), The international handbook of organisational culture and climate (pp. 347-372). Great Britain: John Wiley and Sons.

Donaldson, T., \& Preston, L. (1995). The stakeholder theory of the corporation: concepts, evidence, and implications. Academy of Management Review, 20(1), 65-91.

Doppelt, B. (2003). Leading change toward sustainability. Sheffield, UK: Greenleaf Publishing.

Falko, S. (2008). Theory and practice of controlling on Russia: present state and perspectives. Proceeding of the $2 n d$ ICV Controlling Congress in the Baltic region (pp. 1-33).

Freeman. R. E. (1984). Strategic management: A stakeholder perspective. Englewood Cliffs, N.J.: Prentice Hall.

Geertshuis, S. (2009). Improving decision making for sustainability: A case study from New Zealand. International Journal of Sustainability in Higher Education, 10(4), 379-389.

Heidmets, M. ( 2004). Knowledge-based society, knowledge-based governance (in Estonian). Riigikogu Toimetised, $10,11-17$.

Hemingway, C. A. (2005). Personal values as a catalyst for corporate social entrepreneurship. Journal of Business Ethics, 60(3), 233-249.

Hengstamm, C., \& Becker, J. (2006). Cultural differences of effective leadership: In Sweden, England, France and Germany. Retrieved May 17, 2009, from http://www.essays.se/essay/050005621e/

Hillman, A., \& Keim, G. (2001). Shareholder value, stakeholder management, and social issues: What's the bottom line? Strategic Management Journal, 22(2), 125-139.

Hofstede, G. (1994). Cultural constraints in management theories. International Review of Strategic Management, 5, 27-48.

Hofstede, G. (2001). Culture's consequences: Comparing values, behaviors, institutions and organisations across nations (2nd ed.). California, USA: Sage Publications.

Horngren, C. T., Bhimani, A., Datar, S. M., \& Foster, G. (2005). Management and cost accounting (3rd ed.). Edinburgh, England: Pearson Education Limited.

Horvath, P. (2006). Das controllingkonzept. Der weg zu einem wirkungsvollen controllingsystem. Deutscher Taschenbuch Verlag: München Von Horvath \& Partners.

Humphreys, M., \& Brown, A. D. (2008). An analysis of corporate social responsibility at credit line: A narrative approach. Journal of Business Ethics, 80(3), 403-418.

Husted, B. W. (1999). Wealth, culture and corruption. Journal of International Business Studies, 30(2), 339-360.

Juščius, V., \& Snieška, V. (2008). Influence of corporate social responsibility on competitive abilities of corporations. Engineering Economics, 3(58), 34-44.

Katz, R. L. (1955). Skills of an effective administrator. Harvard Business Review, 33(1), 33-42. 
Kawamura, M. (2004). The evolution of corporate social responsibility in Japan (Part 1). Social Development Research Group, NLI Research Institute.

Kooskora, M. (2008). Understanding corporate moral development in the context of rapid and radical changes. The case of Estonia (Dissertation of the degree of Doctor of Philosophy, University of Yväskylä).

Lyon, D. (2004). How can you help organisations change to meet the corporate responsibility agenda? Corporate Social Responsibility and Environmental Management, 11(3), 133-139.

Matsumoto, D. R. (1996). Culture and psychology. Pacific grove, C.A.: Brooks/Cole Publishing Co..

Matten, D., \& Moon, J. (2004). A conceptual framework for understanding CSR. In A. Habish, J. Jonker, M. Wegner, \& R. Schmidpeter (Eds.), CSR across Europe (pp. 335-356). Berlin: Springer Verlag.

McWilliams, A., \& Siegel, D. (2001). Corporate social responsibility: A theory of the firm perspective. Academy of Management Review, 26(1), 117-127.

Merchant, K. A. (1998). Modern management control systems: Text and cases. Prentice Hall.

Nejati, M., Shahbudin, A. S. B. M., \& Amran, A. B. (2010). Putting sustainability at the core of knowledge management performance evaluation system. Journal of Organisational Knowledge Management, 1-13.

Norris, G., \& Innes, J. (2005). Corporate social responsibility: Case studies for management accountants. Oxford : CIMA.

Reidenbach, R., \& Robins, D. (1991). A conceptual model of corporate moral development. Journal of Business Ethics, 10(4), 273-284.

Review of the European Union Strategy for Sustainable Development. (2010). Retrieved February 20, 2010, from http://ec.europa.eu/sustainable/docs/com_2009_400_en.pdf

Ringov, D., \& Zollo, M. (2007). Corporate responsibility from a socio-institutional perspective. The impact of national culture on corporate social performance. Journal of Effective Board Performance, 7(4), 476- 485.

Rooney, S. (2007). The value of the truly sustainable business strategy. ECOS Magazine, 138(8-9), 27-28.

Rüegg-Stürm, J. (2002). Organizational management mode. Retrieved February 20, 2009, from http:/www.ifb.unisg.ch/org/IfB/ifbweb.nsf/wwwPubInhalteGer/St.Galler+Management-Modell?opendocument

Schein, E. H. (1999). The corporate culture survival guide: Sense and nonsense about culture change. San Francisco: Jossey-Bass.

Scholtens, B., \& Dam, L. (2007). Cultural values and international differences in business ethics. Journal of Business Ethics, 75(3), 273-284.

The web site of Hofstede's works. (2009). Geert hofstede cultural dimensions. Retrieved February 20 , 2009 from http://www.geert-hofstede.com/hofstede_dimensions.php?culture $1=29 \&$ culture $2=34$

Thornton, C. H., \& Jaeger, A. J. (2008). The role of culture in institutional and individual approaches to civic responsibility at research universities. Journal of Higher Education, 79(2), 160-182.

Trompenaars, F., \& Prud'homme van Reine, P. (2004). Managing change across corporate cultures. Great Britain: Capstone Publishing.

Übius, Ü., \& Alas, R. (2009). Organisational culture types as predictors of corporate social responsibility. Engineering Economics, $1(61), 90-99$.

Valentino, B. (2007). MBA toolkit for CSR: Human resources. Retrieved February 20, 2009, from http://www.chinacsr.com/en/2007/03/08/1102-mba-toolkit-for-csr-human-resources/

Vitell, S. J., \& Paolillo, J. G. (2004). A cross-cultural study of the antecedents of the perceived role of ethics and social responsibility. Business Ethics, 13(2-3), 185-199.

Waldman, D. A., de Luque, M. S., Washburn, N., \& House, R. J. (2006). Cultural and leadership predictors of corporate social responsibility values of top management: A globe study of 15 countries. Journal of International Business Studies, 37(6), 823-837.

Weber, J. (2006). Stand und perspektiven des controllings. Paper presented at the conference Controlling Advantage Bonn, Nov. 16, 2006. Unpublished manuscript, Bonn, Germany.

Weber, J., \& Schäffer, U. (2008). Introduction to controlling. Stuttgart: Schäffer-Poeschel Verlag, Recht GmbH.

Wieland, J. (2005). Corporate governance, values management, and standards: A European perspective. Business \& Society, 44(74), 74-93.

Website of CSR Europe. (2009). Barroso: We need a new culture of ethics and responsibility. Retrieved July 18, 2009, from http://www.csreurope.org/news.php?type=\&action=show_news\&news_id=2434

Website of Responsible Business Forum in Estonia. (2009). Vastutustundliku ettevõtluse indeksi tulemused 2009 (in Estonian). Retrieved May 27, 2009, from http://www.csr.ee/4841 